\title{
On Government's Role in Innovating on System of Risk Investment
}

\author{
Wang xie yong \\ (Dalian University, Dalian, Liaoning, China, 116622)
}

\begin{abstract}
:
We should recognize the government's role in the initial establishment of risk investment system, however we wouldn't neglect it's the intervention of administrative power and system that resulted in "administrative" and "planned" capital market. Now what we should do are to counteract the administrative influence on innovation upon risk investment system, to bring government's role in guiding and supporting into full play, to mobilize more innovators and to transit the government's traditional role in the system of risk investment.
\end{abstract}

\section{Keywords:}

innovation in system, risk investment, major investors

Innovation in system is an eternal subject in during the developing process of capital market, and also a force driving it to advance continuously. Chinese capital market formed from friction and contradiction in transition from the old economic system to the new, so being very "Chinese" was the first defect of capital market. But we've to face such as face that when China transited planned economy to market-directed economy, the people had an inappropriate conception of risk investment.

\section{Government's role in the system of risk capital market}

Development of risk investment should be a basic policy to drive science, technology, especially hi-tech industries to develop, and brought into China's general program for the medium and long-term development of national economy and society. The government may use may methods, such as direct investment, low interest loan, tax concession, compensation for risk, loan on security, and so on, to support risk investment and to establish a rational system of risk capital market.

\subsection{Playing government's role in propaganda and} directing, and cultivating a sense of risk investment

Risk investment is just an engenderment novelty in many countries, especially in China. Most people have not a clear idea about its concept, characteristics and running process.

That is to say they have a weak sense and a poor knowledge of risk investment. What so many people care is only its high risk instead of great proceeds. As economy develops and main economic actors' income rose higher, a undercount shows that by October 2012, Chinese residents' deposit has amounts to RMB 89.68trillion, foreign currency deposit to USD 480.6 billion, enterprisers' to several trillion, and various funds to several hundred billion. Furthermore, continuous reduction in interest on deposit in Bank, a huge sum of idle fund in the society is sure to find a new way to maintain or add its value. From the above we can see, development of risk investment is feasible in China. The government should popularize the knowledge of risk investment by media or introducing foreign experience in success to give people a sense of risk and a correct conception of investment, and to have them know that great proceeds come from high risk and only bold investment could make great success. In addition, risk investment needs a large sum of money, and feature long period and big risk, so the government should provide necessary support and aid for risk firms by means of tax concession, financial guarantee, compensation for risk loss, low interest loan, and etc. that can reduce their burden in initial stage, and encourage their innovative spirit. 


\subsection{Government opens risk investment company}

The government can open a risk investment company by state appropriated funds, people's financial support, issuing risk bond or absorbing foreign investments. There are three investment forms: the first one is investing $\mathrm{R} \& \mathrm{D}$ funds that are mainly used for some fundamental or key scientific research. In fact, “863 Plan” carried out by Chinese government in 1986 as well as "Torch Plan" in 1988 were two risk investment plans. The second is issuing issue a guarantee for investment. For example, USA, UK, Japan and Taiwan all have different "Guarantee Plans for Investment”. According to foreign experience and conclusions, the government shall put stress on hi-tech industries. When hi-tech achievements are transformed, a large sum of money demanded. Speeding up combination of hi-tech industries with capital market and promoting development of risk investment in hi-tech industries are favor of the transformation of hi-tech achievements, the combination of science with economy, and promoting development of the whole national economy. The third is direct investment. For example, UK, Japan, Singapore and Israel all have made direct risk investment. Different from the first one, this form should be oriented by market. Upon research and comparison, we can see government's direct investment should be limited to a certain field and duration. The government would better directly operate risk investment fund, but authorize an investment management company. On the other hand, the government The government should directly supervise, control and assess their investment, and establish a rational and operable judging system.

\subsection{Government makes investment plans for policy}

Investment plan for policy covers both organizations and individuals. Favorable policy for organizations includes low-interest loan and capital gains tax concession, such as in USA, Singapore, Taiwan and Japan. Favorable policy for individuals includes concession of individual income regulatory taxes and death tax, such as in USA, Singapore, Taiwan and Japan. In addition, free of ground rent for a short term, low ground rent for a long term, and allowance for loss in investment are acceptable. In view of the practical situation of China, favorable policy should be better available to risk investment company, especially when they sustain losses in investment, a certain tax concession for them is recommended. And they're even allowed to deduct part of all losses from their income $\operatorname{tax}$.

On one hand, the government should play a guiding role in the field of investment. On the other hand, it should utilize foreign experience, i.e. offer investment but not operate it directly, and at last, draw it back by allowance, guarantee, tax concession, establish of secondary market, and etc.

\subsection{Financing by government's credit, financial institution, corporate enterprises, and the public}

In this aspect, it's impossible for us to imitate USA to mainly use investor's funds (including old-age pension reserve fund, reserve fund for college education) for risk investment, because China's reform of welfarism was just in early stage. Moreover, the government couldn't depend on bank, especially commercial state banks. It's just the above situations that limit the most risk capital to the social public.

Practice proofs that a risk investment company invested directly or indirectly by government offers advantage of capital infusion, and can orient the risk capital market and hi-tech industry. The more risk investment companies are founded by government, the more investors will be attracted.

\section{Government's role in major risk investors}

System of risk investment is composed of different organs, investment fields and investment stages. It's improper for government to always play the major role in any risk investment organ. But it's obvious that it's very hard to run a risk investment company smoothly without government's investment in China. So it's a key problem that how a government play its role of investor properly. In my views, government's influence should be counteracted on risk investment in industrialized projects, and it should turn to support the venture capital for rapid development. Evolvement of risk capital market shows that when risk investment 
industry starts developing, government should resign from the leading position. But that's not to neglect its role in its irreplaceable role in the early stage of risk investment.

At present, most risk investment organs are corporations founded by government, listed company or group. The leading position of those founded by government is vacant; in those founded by listed companies, the decision about investment is often impeded by big shareholder; bad controlling and inspiriting system and inconstantly rational investment of risk investment operators result from immature risk investment climate, late emergence of growth enterprise market, incomplete channels of withdrawal of risk investment, imperfect legal system for limited liability partnership, and etc.

Risk investment business develops following the state of the art. During developing, some legal operation, such as insider dealing and playing the market would occur. For this reason, government has to regulate and supervise risk investment for its smooth running. Most risk investors are risk investment companies, holders of risk fund, angel investors, planning investors, hi-tech enterprises, and etc. participators in risk investment include governments, financial organs, scientific research institutions, assessing organs, law offices, securities markets, and etc. Whether the major investors and participators' action is normative or not is a key factor to the normative of risk investment. Now the state should enact appropriate law, rules and policies, create a good environment for risk investment, explore a new capital market for hi-tech industries, and unbar the channels of financing and risk investment by minor enterprises engaged in science and technology.

Lastly, we'll point out that direct participation of government in risk investment business is determined by the practical situation of China. But, as this business develops and gets to be mature, government should counteract its control on it, but exert its role in leading, supporting, guiding and organizing.

\section{Government's role in withdrawal system of risk capital}

Risk investment features primary risks, a large sum of investment and great returns. An expedite channel of drawback of invested fund is a necessary condition for achieving great returns. Now there is no securities market in China for hi-tech businesses (generally called the secondary market), or perfect market of transactions of property rights or relevant laws, which fiercely impedes investors withdrawing value-added fund or realizing property right.

As generally deemed that transferring stock is the only way of risk investor to withdraw his risk investment. But in fact, it's an ideal way. Limited by the practical situation of China, it's unpractical to set a normative secondary market in a short term. But we couldn't cease to go on despite the above reason. A feasible way to withdraw risk investment is to "go abroad, introduce in, develop step by step and achieve a goal in stages".

The first: we'd better use the method of "going abroad". E.g. China Web was listed at Wall Street Securities on Jul. 13, 2000. It's a successful example that Chinese enterprise entered America market.As another report, in this period of drastic decline in international economy, some American companies turned their attention to Chinese enterprises of great capacities.

The second: developing the capabilities of domestic capital market, and using the method of "introducing in". I.e. learning from foreign experience in merging and purchasing enterprise to realize withdrawal of risk capital. China Economic and Trading Committee definitely advocated encouraging powerful nongovernmental enterprises engaged in science and technology to participate in reform and practice of minor enterprises by becoming shareholder, renting, merging or purchasing them, and to establish modern corporate system.

The third: using method of "developing step by step and achieving a goal in stages" to establish a secondary securities market and to perfect the channel 
of withdrawal of risk capital. The secondary market is considered highly important for prospering minor enterprises, especially those engaged in hi-tech industries.

\section{Government's role in training talented risk investors}

Most Chinese people have not a clear idea about its concept, characteristics and running process. That is to say they have a weak sense and a poor knowledge of risk investment. What so many people care is only its high risk instead of great proceeds. The government should popularize the knowledge of risk investment by media or introducing foreign experience in success to give people a sense of risk and a correct conception of investment, and to have them know that great proceeds come from high risk and only bold investment could make great success. In addition, risk investment needs a large sum of money, and feature long period and big risk, so the government should provide necessary support and aid for risk firms by means of tax concession, financial guarantee, compensation for risk loss, low interest loan, and etc. that can reduce their burden in initial stage, and encourage their innovative spirit.

Success in risk investment depends on investor's proper judgment on market outlook and entrepreneur's capability. Foreign experience in success shows that talented enterprising risk investor who has a mastery of both engineering and business management, a strong sense of risk, an rich experience in financial investment, a steel courage, and a sound knowledge of hi-tech invention is indispensable for successful risk investment. In order of priority, key factors to successful risk investment are entrepreneur, market outlook, and then level of technology. Risk investors generally deem:

Advanced technology + bad management $=$ defeat Ordinary technology + good management $=$ possible success

Government should mobilize risk investment organs to provide fund, instructions and advices for enterprise's business, or to recommend talented persons to participate in business management. It should intensify reform in senior higher education, set courses of hi-tech application and risk investment, and list some subjects in connection to risk investment as basic courses of ever major with aim to enrich students with diversified knowledge and to strengthen their capabilities of settling complex practical problems. Universities and colleges should make good use of their advantages in talented persons and scientific research to train qualified talents for risk investment enterprise, intensify training of business backbones in knowledge of risk investment, or send them abroad for advanced learning. In addition, it's a also good idea to invite overseas experts in risk investment for instructions, to learn from foreign experience in success, and expand the team of talented persons in risk investment, because only by doing that, the China's risk investment industry can advance continuously.

\section{References:}

[1] Cui Zheng-zhuo.The Research on the Government Function during the Development of China's Venture Capital Market[D].Liaoning University.2012(05).

[2] Lu Shan,Zhao Li-ming. Study on the Influence of Taxation and Finance Subsidy on Cooperative Behavior between Business Incubator and Venture Capital[J]. Soft Science. 2011(11).

[3] Baker, G. P,T. N Hubbard.Contractibility and asset ownership:on-board computers and governance in U.S. trucking. Quarterly Journal of Econmics . 2004(03). 